\title{
PARTYCYPACJA PUBLICZNA W POLSKICH MIASTACH I MIASTECZKACH NA PRZYKŁADZIE WOJEWÓDZTWA POMORSKIEGO
}

\section{Abstract \\ Public participation in Polish towns and medium-sized cities in Pomeranian Voivodeship}

We are living in the area of cities and mayors. Local authorities are more and more effective, sometimes it looks like they even take over the role of state governments. But it is about cities. Is there a place for towns and their residents in processes of global urbanization and public participation? The article is focused on participatory process in medium-sized cities and towns in Pomeranian Voivodeship in Poland. It is based on own research (interviews with local authorities and non-governmental organizations), analysis of websites of town halls and city offices, acts of local law, reports on public consultation. The research indicates shortcomings in the implementation of residents' rights to take part in public participation processes. They are visible at the lowest level of the process, i.e. access to information. In the small and medium-sized cities of the Pomeranian Voivodship, social consultations are conducted, however, it is still far from public participation.

Keywords: public participation, public consultations, medium-sized cities, towns

\section{Streszczenie}

Miasta podbijają świat: coraz większy odsetek ludności zamieszkuje miasta, władze miast stają się skuteczniejsze niż władze państwowe. Czy w tych procesach jest miejsce na głos mieszkańców małych miast i miasteczek? Celem artykułu jest analiza możliwości udziału w procesach partycypacji publicznej mieszkańców małych i średnich miast na przykładzie województwa pomorskiego. Podstawą są badania własne autorki - wywiady i ankiety z przedstawicielami jednostek samorządu terytorialnego, organizacji pozarządowych, analiza stron internetowych urzędów miast, uchwał, a także raporty i wnioski z prowadzonych konsultacji społecznych. Przeprowadzone badania wskazują na niedostatki w realizacji uprawnień mieszkańców do udziału w procesach partycypacji publicznej. Widoczne są one już na najniższym szczeblu 
procesu, czyli dostępie do informacji. W małych i średnich miastach województwa pomorskiego prowadzone są konsultacje społeczne, nie można jednak mówić o pełnej partycypacji publicznej.

Słowa kluczowe: partycypacja publiczna, konsultacje społeczne, małe miasta, średnie miasta

\section{Uwagi wstępne}

Dynamiczne procesy urbanizacyjne nie omijają Polski. Obecnie $60 \%$ ludności zamieszkuje miasta ${ }^{1}$, niemal jedna trzecia Polek i Polaków mieszka w małych i średnich miastach (32\%) [Bank danych lokalnych, stan na 31.12.2017]. Rosnąca siła miast, nie tylko w wymiarze demograficznym i społecznym, ale także gospodarczym, rodzi pytanie o ich miejsce w systemach politycznych. Benjamin Barber stawia tezę, że w czasach niepewności i poszerzającego się pola zagrożeń (zmiany klimatu, terroryzm, przestępczość) państwa stają się dysfunkcjonalne. Miasta i ich władze okazują się zaś podmiotami, które łatwiej i efektywniej radzą sobie ze współczesnymi wyzwaniami. Barber w swojej książce odnosi się przede wszystkim do światowych metropolii, z miast polskich pojawiają się Warszawa, Gdańsk i Wrocław (zaliczane przez autora do kategorii miast średnich) [Barber, 2014]. Miasta te szeroko włączają w procesy zarządzania swoich mieszkańców ${ }^{2}$. Sytuacja ta dotyczy jedynie mieszkańców dużych miast, czyli w Polsce - ponad jednej czwartej mieszkańców (28\%) [Bank danych lokalnych, stan na 31.12.2017].

Autorka w swoim opracowaniu zajmuje się pozostałymi mieszkańcami polskich miast - analizuje miejsce mieszkańców małych i średnich miast w procesach zarządzania na poziomie samorządu gminnego, stawiając wstępną hipotezę o ograniczonym dostępie obywateli do procesów partycypacji publicznej. Szuka odpowiedzi na następujące pytania:

1) W jakim zakresie władze lokalne umożliwiają mieszkańcom udział w procesach konsultacji i partycypacji?

1 W opracowaniu przyjęto podział miast przy wykorzystaniu kryterium statystycznego - liczby ludności. Miasta małe to te do 20 tys. mieszkańców, średnie od 20 do 100 tys. mieszkańców, duże powyżej 100 tys. mieszkańców [Rybicki, 1972].

2 W Warszawie działa odrębny wydział zajmujący się procesami konsultacji społecznych (Wydział Konsultacji Społecznych i Współdecydowania z Mieszkańcami Centrum Komunikacji Społecznej Urzędu Miasta Stołecznego Warszawy), miasto ma także stronę dedykowaną wyłącznie tej kwestii [Konsultacje społeczne...], w Gdyni partycypacją zajmuje się zaś odrębna jednostka - Laboratorium Innowacji Społecznych [Laboratorium innowacji...]. Osobne wydziały mają także Gdańsk i Wrocław (oraz większość dużych miast w Polsce), dynamicznie działają tam rady dzielnic/ osiedli i organizacje pozarządowe. Działają także zespoły konsultacyjne (np. w Gdańsku Rada ds. Równego Traktowania czy Rada Imigrantów i Imigrantek) [Gdańsk - oficjalny...]. Duże miasta wprowadzają innowacyjne w skali kraju metody włączania mieszkańców w procesy decydowania, np. sąd obywatelski w Poznaniu czy panel obywatelski w Gdańsku. 
2) W jaki sposób władze lokalne umożliwiają udział mieszkańców w procesach konsultacji i partycypacji?

3) Jak przebiega proces komunikacji między władzą a mieszkańcami w trakcie konsultacji społecznych?

4) Czy procesy te spełniają warunki Kanonu lokalnych konsultacji społecznych [2015]? ${ }^{3}$

Podstawą są badania własne autorki - wywiady i ankiety z przedstawicielami jednostek samorządu terytorialnego (dalej: JST), organizacji pozarządowych, analiza stron internetowych urzędów miast, uchwały rad gmin i miast, a także raporty oraz wnioski z prowadzonych konsultacji społecznych.

\section{Partycypacja publiczna - podstawowe pojęcia}

Partycypacja publiczna jest pojęciem najszerszym spośród tych opisujących aktywność obywatelską czy społeczną. To aktywna obecność obywateli w procesach stanowienia i realizacji polityk publicznych, projektów, programów, inwestycji. W dyskursie pojawiają się także pojęcia: dialog społeczny, dialog obywatelski, konsultacje społeczne/publiczne, demokracja partycypacyjna, partycypacja społeczna, partycypacja obywatelska. Poniżej przedstawiono propozycję usystematyzowania tychże definicji. Dialog społeczny to element społecznej gospodarki rynkowej, dotyczy komisji trójstronnej, gdzie spotykają się przedstawiciele rządu, pracodawców i związków zawodowych [preambuła do Konstytucji Rzeczpospolitej Polskiej z dnia 2 kwietnia 1997 roku], Dialog obywatelski to udział organizacji pozarządowych w zarządzaniu państwem [Misztal, 2008]. Konsultacje społeczne to instytucja demokracji bezpośredniej, w ramach której władze proszą mieszkańców i obywateli o opinie, które nie mają jednak charakteru wiążącego [ustawa z dnia 8 marca 1990 r. o samorządzie gminnym]. Demokracja partycypacyjna opiera się na zasadach demokracji przedstawicielskiej, z włączeniem obywateli do codziennego podejmowania decyzji [Schimanek, 2015]. Partycypacja społeczna to zaangażowanie jednostek w życie społeczne.

\section{Partycypacja publiczna w miastach}

Możliwości partycypacji publicznej mieszkańców miast określają przede wszystkim ustawy dotyczące samorządu gminnego. Najszerzej kwestie reguluje ustawa

3 Z inicjatywy Ministerstwa Administracji i Cyfryzacji wypracowano siedem zasad konsultacji, włączonych do Kanonu lokalnych konsultacji społecznych [2015]. Podstawowe zasady współpracy z władzy z mieszkańcami to: dobra wiara, powszechność, przejrzystość, responsywność (odpowiedź na zgłoszone wnioski, uwagi, pomysły), koordynacja, przewidywalność, poszanowanie interesu ogólnego. 
z dnia 8 marca 1990 r. o samorządzie gminnym, która wskazuje szereg obligatoryjnych i fakultatywnych wskazań do prowadzenia konsultacji społecznych. Zawiera zapis o możliwości prowadzenia konsultacji społecznych w każdej ważnej dla mieszkańców sprawie, otwiera więc szerokie pole do angażowania mieszkańców w procesy decyzyjne. Na poziomie miasta partycypacja może być prowadzona także na potrzeby rewitalizacji, planowania przestrzennego, ochrony środowiska, organizacji pozarządowych, oświaty i sportu. Zestawienie zawiera tabela 1.

Tabela 1

Możliwości partycypacji w miastach w wybranych ustawach

\begin{tabular}{|c|c|c|c|}
\hline Lp. & Podstawa prawna & Przedmiot, zasady & Interesariusze \\
\hline 1. & $\begin{array}{l}\text { ustawa z dn. } 8 \text { marca } 1990 \text { r. } \\
\text { o samorządzie gminnym } \\
\text { (Dz.U. 2019, poz. } 506 \text { tekst } \\
\text { jedn.) }\end{array}$ & $\begin{array}{l}\text { obowiązkowe: zmiana granic } \\
\text { gminy, organizacja i zakres } \\
\text { działania jednostek pomoc- } \\
\text { niczych, budżet obywatelski } \\
\text { w miastach na prawach po- } \\
\text { wiatu } \\
\text { fakultatywne w każdej ważnej } \\
\text { dla gminy kwestii, młodzieżo- } \\
\text { wa rada miasta, rada seniorów } \\
\text { zasady prowadzenia na pod- } \\
\text { stawie uchwały rady gminy }\end{array}$ & $\begin{array}{l}\text { wszyscy mieszkańcy (kryte- } \\
\text { rium miejsca zamieszkania) }\end{array}$ \\
\hline 2. & $\begin{array}{l}\text { ustawa z dn. } 9 \text { października } \\
2015 \text { r. o rewitalizacji (Dz.U. } \\
2018 \text {, poz. } 1398 \text { tekst jedn. } \\
\text { ze zm.) }\end{array}$ & $\begin{array}{l}\text { fakultatywnie: gminny pro- } \\
\text { gram rewitalizacji, komitet } \\
\text { rewitalizacji, miejscowy plan } \\
\text { rewitalizacji }\end{array}$ & $\begin{array}{l}\text { mieszkańcy, przedsiębiorcy, } \\
\text { właściciele, organizacje poza- } \\
\text { rządowe }\end{array}$ \\
\hline 3. & $\begin{array}{l}\text { ustawa z dn. } 27 \text { marca } 2003 \text { r. } \\
\text { o planowaniu i zagospo- } \\
\text { darowaniu przestrzennym } \\
\text { (Dz.U. 2018, poz. } 1945 \text { tekst } \\
\text { jedn. ze zm.) }\end{array}$ & $\begin{array}{l}\text { obowiązkowe: informowanie } \\
\text { i konsultowanie - włączanie } \\
\text { mieszkańców i organizacji } \\
\text { społecznych w tworzenie do- } \\
\text { kumentów dotyczących zago- } \\
\text { spodarowania przestrzennego }\end{array}$ & wszyscy zainteresowani \\
\hline 4. & $\begin{array}{l}\text { ustawa z dn. } 15 \text { września } \\
2000 \text { r. o referendum lokal- } \\
\text { nym (Dz.U. 2019, poz. } 741 \\
\text { tekst jedn.) }\end{array}$ & $\begin{array}{l}\text { fakultatywne: referendum } \\
\text { opiniodawcze }\end{array}$ & $\begin{array}{l}\text { wszyscy mieszkańcy (kryte- } \\
\text { rium praw wyborczych) }\end{array}$ \\
\hline
\end{tabular}




\begin{tabular}{|c|c|c|c|}
\hline 5. & $\begin{array}{l}\text { ustawa z dn. } 24 \text { kwietnia } \\
2003 \text { r. o działalności pożytku } \\
\text { publicznego i o wolontariacie } \\
\text { (Dz.U. } 2019 \text {, poz. } 688 \text { tekst } \\
\text { jedn.) }\end{array}$ & $\begin{array}{l}\text { obowiązkowe: projekty aktów } \\
\text { prawa miejscowego związa- } \\
\text { nych z działalnością organiza- } \\
\text { cji pozarządowych, rocznych } \\
\text { i wieloletnich programów } \\
\text { współpracy } \\
\text { fakultatywne: inicjatywa lo- } \\
\text { kalna, rada działalności pożyt- } \\
\text { ku publicznego }\end{array}$ & organizacje pozarządowe \\
\hline 6. & $\begin{array}{l}\text { ustawa z dn. } 27 \text { kwietnia } \\
2001 \text { r. Prawo ochrony środo- } \\
\text { wiska (Dz.U. 2018, poz. } 799 \\
\text { tekst jedn. ze zm.) }\end{array}$ & $\begin{array}{l}\text { obowiązkowe: informowanie } \\
\text { i konsultowanie, włączanie } \\
\text { mieszkańców i organizacji } \\
\text { społecznych w tworzenie po- } \\
\text { lityk publicznych dotyczących } \\
\text { ochrony środowiska }\end{array}$ & $\begin{array}{l}\text { wszyscy mieszkańcy, } \\
\text { organizacje ekologiczne }\end{array}$ \\
\hline 7. & $\begin{array}{l}\text { ustawa z dn. } 3 \text { października } \\
2008 \text { r. o udostępnianiu in- } \\
\text { formacji o środowisku i jego } \\
\text { ochronie, udziale społeczeń- } \\
\text { stwa w ochronie środowiska } \\
\text { oraz o ocenach oddziaływania } \\
\text { na środowisko (Dz.U. } 2018 \text {, } \\
\text { poz. } 2081 \text { tekst jedn. ze zm.) }\end{array}$ & $\begin{array}{l}\text { obowiązkowe: informowanie } \\
\text { i konsultowanie, włączanie } \\
\text { mieszkańców i organizacji } \\
\text { społecznych w tworzenie po- } \\
\text { lityk publicznych dotyczących } \\
\text { ochrony środowiska }\end{array}$ & $\begin{array}{l}\text { wszyscy mieszkańcy, orga- } \\
\text { nizacje ekologiczne }\end{array}$ \\
\hline 8. & $\begin{array}{l}\text { ustawa z dn. } 25 \text { czerwca } \\
2010 \text { r. o sporcie (Dz.U. 2018, } \\
\text { poz. } 1263 \text { tekst jedn. ze zm.) }\end{array}$ & fakultatywne: rady sportu & $\begin{array}{l}\text { organizacje pozarządowe zaj- } \\
\text { mujące się sportem i kulturą } \\
\text { fizyczną }\end{array}$ \\
\hline 9. & $\begin{array}{l}\text { ustawa z dn. } 7 \text { września } \\
1991 \text { r. o systemie oświaty } \\
\text { (Dz.U. } 2018 \text {, poz. } 1457 \text { tekst } \\
\text { jedn. ze zm.) }\end{array}$ & fakultatywne: rady oświatowe & wszyscy mieszkańcy \\
\hline
\end{tabular}

Źródło: opracowanie własne na podstawie danych rozproszonych (w ustawach).

Najbardziej uporządkowany i rozbudowany proces partycypacji na poziomie miast wskazują: ustawa o planowaniu i zagospodarowaniu przestrzennym oraz ustawa o rewitalizacji.

Ustawa $\mathrm{z}$ dnia 27 marca 2004 r. o planowaniu i zagospodarowaniu przestrzennym określa potrzebę i zasady konsultacji, wprowadza obowiązek udziału zainteresowanych podmiotów zarówno na początku, jak i na końcu procesu sporządzania dokumentów planistycznych oraz obowiązek zróżnicowanych form konsultacji (pisemne i interaktywne - dyskusja publiczna). Ustawa z dnia 9 października $2015 \mathrm{r}$. o rewitalizacji po raz pierwszy wprowadza określenie „partycypacja społeczna” (proces obejmujący nie tylko sporządzanie dokumentów, ale również etapy ich 
realizacji i oceny projektów czy polityk). Partycypację opisuje odrębny rozdział. Pojawia się lista interesariuszy (art. 2 pkt 2). Wskazany jest sposób przygotowania oraz udostępniania raportów i dokumentacji procesu. Ustawa ukazuje potrzebę realizacji działań partycypacyjnych blisko interesariuszy, w czasie dopasowanym do ich trybu życia. Wymienia także katalog narzędzi partycypacji: konsultacje pisemne, spotkania, debaty, warsztaty, spacery studyjne, ankiety, wywiady, wykorzystanie grup przedstawicielskich lub zbieranie uwag ustnych (art. 5-7).

Największą wadą wszystkich regulacji wskazanych w powyższej tabeli jest doradczy charakter konsultacji, gdyż ich wynik w żadnym z wypadków nie jest wiążący dla władz.

Regulacje ustawowe, mimo dobrych chęci ustawodawcy, mogą utrudniać realizowanie procesów partycypacyjnych. Przykładem może być budżet obywatelski, zapoczątkowany jako nowatorskie narzędzie współdecydowania w Sopocie. Inicjatorami procesu byli przedstawiciele Sopockiej Inicjatywy Rozwojowej [Sopocka Inicjatywa...]. Obecnie rozwiązania angażujące w większym stopniu mieszkańców testuje Dąbrowa Górnicza [Twoja Dąbrowa...]. Zgodnie z nowelizacją z dnia 11 stycznia 2018 roku ustawy z dnia 8 marca 1990 r. o samorządzie gminnym od roku $2019^{4}$ budżet obywatelski ma stać się obowiązkowym narzędziem konsultacji społecznych (art. 5a pkt 3-7). Budżet obywatelski ma wynosić co najmniej $0,5 \%$ budżetu gminy, projekty wybierane mają być w głosowaniu bezpośrednim. Dla miast stosujących bardziej rozbudowane czy innowacyjne formy współdecydowania zapis ustawowy może być krokiem wstecz.

Pomimo ograniczeń - na poziomie gminy obywatele czują większą możliwość wpływu na swoje sprawy. Poczucie sprawczości na poziomie miasta, gminy deklaruje do 60\% Polaków. Na poziome kraju takie deklaracje składa maksymalnie $41 \%$ Polaków.

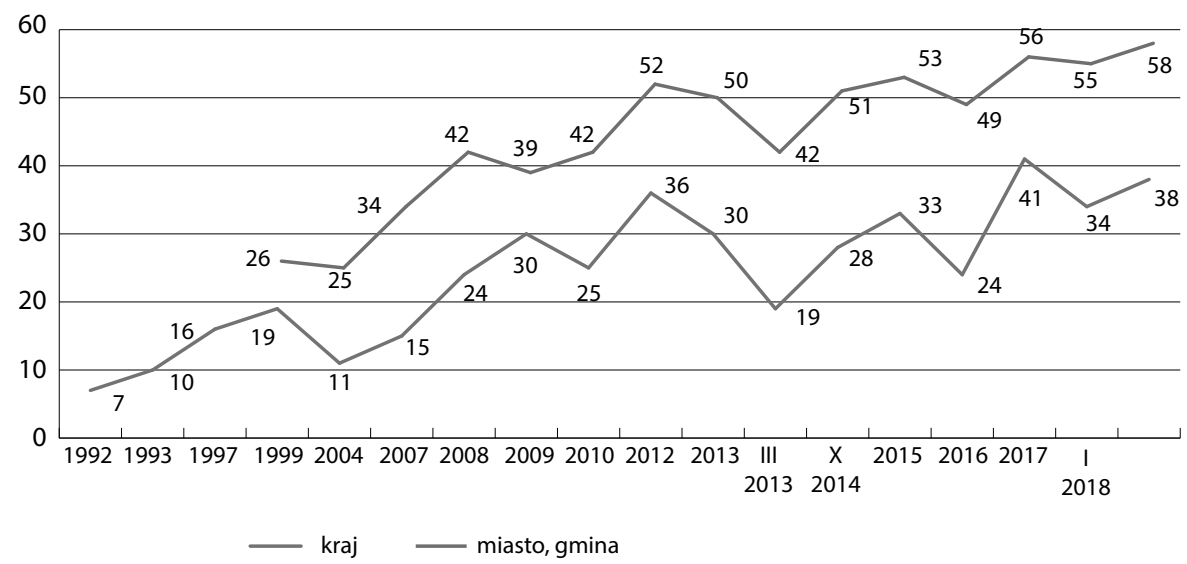

Ryc. 1. Poczucie wpływu na sprawy publiczne w procentach

Źródło: Poczucie wpływu..., 2018: 2-3.

4 W roku 2018 budżet obywatelski działał we wszystkich miastach na prawach powiatu i miastach powiatowych w województwie pomorskim. 
Mieszkańcy mniejszych miast są bardziej krytyczni w ocenie władz lokalnych, co także może sprzyjać większemu zaangażowaniu w życie wspólnoty. Dobrze swoich włodarzy ocenia niespełna połowa mieszkańców małych miast (46\%) i prawie dwie trzecie mieszkańców miast powyżej 200 tys. ludności (61\%).

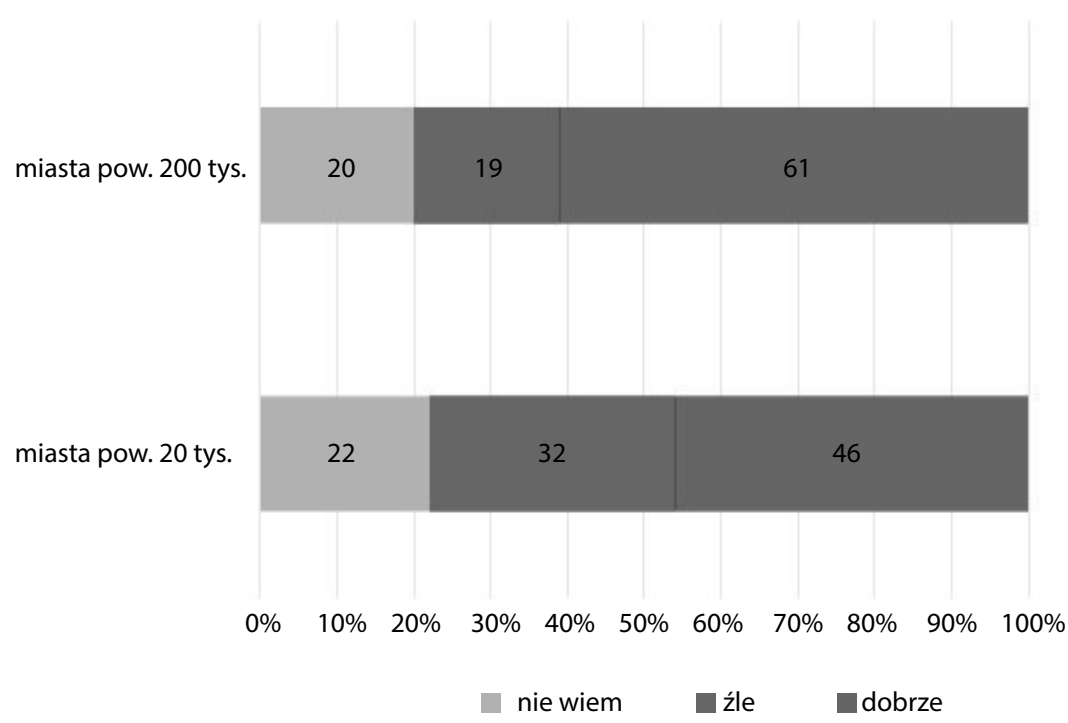

Ryc. 2. Ocena władz lokalnych

Źródło: Światła małego..., 2017: 86.

\section{Małe i średnie miasta w Polsce}

Znaczenie miast dla rozwoju kraju wyraźnie wyartykułowane zostało w Strategii na rzecz odpowiedzialnego rozwoju (dalej: SOR) 5 [uchwała nr 8 Rady Ministrów z dnia 14 lutego 2017 r.], szczególnie w celu strategicznym nr 2: „Rozwój społecznie wrażliwy i terytorialnie zrównoważony". Ma to być rozwój oparty na indywidualnych czynnikach endogennych, lokalnych i regionalnych przewagach konkurencyjnych, wykorzystujący skuteczne narzędzia zarządzania, którego efekty dostępne są dla wszystkich mieszkańców. W SOR wskazane są główne zagrożenia realizacji tego podejścia na terenach miejskich: degradacja przestrzenna,

5 Znaczenie miast i zaangażowania mieszkańców dla rozwoju społecznego i gospodarczego wskazują również dokumenty Organizacji Narodów Zjednoczonych [Nowa Agenda ..., 2016] i Unii Europejskiej [Urban Agenda ..., 2016]. Znaczenie miast podkreślają również Krajowa Polityka Miejska 2023 oraz Koncepcja Przestrzennego Zagospodarowania Kraju 2030. 
zmiany klimatu, zanieczyszczenie powietrza, zaniedbania w zakresie utrzymania infrastruktury technicznej i mieszkaniowej, bezrobocie, ubóstwo, patologie społeczne, rozpad więzi społecznych i rodzinnych, migracje za pracą, niekontrolowana suburbanizacja. Wśród przyczyn tego stanu wskazano: spadek liczby mieszkańców, starzenie się społeczności, niedopasowanie podaży do popytu na rynku pracy, osłabienie bazy ekonomiczno-budżetowej samorządów czy niewystarczającą dostępnością transportową.

SOR wskazuje kierunki służące rozwiązaniu tych problemów. Jednym z nich jest wprowadzanie i upowszechnianie partycypacji publicznej - włączanie mieszkańców w procesy podejmowania decyzji i zarządzania miastami, tak aby uwzględniano zróżnicowane potrzeby użytkowników przestrzeni miejskich.

Oprócz celów szczegółowych SOR wyznacza tzw. horyzontalne cele rozwoju, wśród nich rozwój kapitału społecznego. Tutaj ponownie podkreśla się znaczenie partycypacji publicznej, między innymi: usprawnianie procesów konsultacji społecznych, poprawę komunikacji administracji publicznej ze społeczeństwem, poprawę umiejętności organizacji debat publicznych w istotnych dla społeczeństwa sprawach, wspieranie współpracy międzysektorowej i dialogu społecznego, promocję mechanizmów opartych na zasadach Rozwoju Lokalnego Kierowanego przez Społeczność (RLKS).

Na etapie przygotowania założeń SOR przeprowadzona została analiza sytuacji miast średnich [Śleszyński, 2016]. Wykazała ona, że połowa miast średnich w Polsce zagrożona jest utratą funkcji społeczno-gospodarczych (122 z 255 analizowanych miast). Analizę przeprowadzono na podstawie siedmiu wskaźników (za lata 2004-2014): zmiany rejestrowanej liczby ludności, liczby bezrobotnych, dochodów własnych gmin, liczby udzielonych noclegów, liczby zarejestrowanych przedsiębiorstw, siedziby największych spółek oraz prognozowanej przez GUS liczby ludności do 2035 roku. Rozszerzone analizy obszarów problemowych i wzrostu ujmowały także aktywność społeczną mieszkańców na podstawie frekwencji wyborczej [Śleszyński i in., 2017]. Zaobserwować można więc rosnącą świadomość znaczenia aktywności społecznej i obywatelskiej, także partycypacji publicznej, jako czynników rozwoju.

\section{Małe i średnie miasta w województwie pomorskim}

W województwie pomorskim zlokalizowane są 42 miasta, 40 z nich to miasta małe lub średnie. 64\% mieszkańców województwa żyje w miastach, 33\% mieszkańców województwa pomorskiego zamieszkuje miasta małe i średnie [Bank danych lokalnych, stan na 31.12.2017].

Do kategorii miast dużych należą jedynie Gdańsk i Gdynia. Tak więc 5\% pomorskich miast to miasta duże, 31\% średnie, $64 \%$ małe. Spośród analizowanych miast małych i średnich 2 to miasta na prawach powiatu (Sopot i Słupsk), 21 to gminy miejskie, 17 to gminy miejsko-wiejskie. Liczba ludności waha się od 1,3 tys. mieszkańców Krynicy Morskiej do 91,5 tys. w Słupsku. W 19 miastach mieszka 
mniej niż 10 tys. osób, w 2 powyżej 50 tys. osób. Największa liczba miast zlokalizowana jest $w$ ramach aglomeracji gdańskiej. Połowa pomorskich miast, w tym 19 miast małych i średnich, zrzeszonych jest w Stowarzyszeniu Obszar Metropolitalny Gdańsk Gdynia Sopot [Obszar Metropolitalny...]. Na liście 122 miast średnich tracących funkcje społeczno-gospodarcze znalazły się jedynie 3 miasta województwa pomorskiego: Malbork (silna utrata funkcji, niekorzystna sytuacja społeczno-gospodarcza), Bytów (utrata funkcji, mocno niekorzystna sytuacja społeczno-gospodarcza) i Słupsk (utrata funkcji, niekorzystna sytuacja społeczno-gospodarcza) [Śleszyński, 2016].

Tabela 2

Charakterystyka małych i średnich miast w województwie pomorskim ${ }^{6}$

\begin{tabular}{|c|c|c|c|c|c|}
\hline Lp. & Miasto & Lokalizacja & Typ gminy & $\begin{array}{c}\text { Liczba ludności } \\
\text { (stan na } \\
\text { 31.12.2017) }\end{array}$ & $\begin{array}{c}\text { Powierzchnia } \\
\text { w ha (stan na } \\
31.12 .2017 \text { ) }\end{array}$ \\
\hline 1. & Brusy & powiat chojnicki & miejsko-wiejska & 5209 & 520 \\
\hline 2. & Bytów & powiat bytowski & miejsko-wiejska & 16983 & 872 \\
\hline 3. & Chojnice & powiat chojnicki & miejska & 39937 & 2104 \\
\hline 4. & Czarna Woda & $\begin{array}{c}\text { powiat } \\
\text { starogardzki }\end{array}$ & miejsko-wiejska & 2841 & 994 \\
\hline 5. & Czarne & $\begin{array}{c}\text { powiat } \\
\text { czluchowski }\end{array}$ & miejsko-wiejska & 5983 & 4643 \\
\hline 6. & Czersk & powiat chojnicki & miejsko-wiejska & 9909 & 973 \\
\hline 7. & Człuchów & $\begin{array}{c}\text { powiat } \\
\text { człuchowski }\end{array}$ & miejska & 13869 & 1278 \\
\hline 8. & Debrzno & $\begin{array}{c}\text { powiat } \\
\text { człuchowski }\end{array}$ & miejsko-wiejska & 5152 & 751 \\
\hline 9. & Dzierzgoń & powiat sztumski & miejsko-wiejska & 5413 & 390 \\
\hline 10. & Gniew & powiat tczewski & miejsko-wiejska & 6791 & 604 \\
\hline 11. & Hel & powiat pucki & miejska & 3373 & 2172 \\
\hline 12. & Jastarnia & powiat pucki & miejska & 2736 & 431 \\
\hline 13. & Kartuzy & powiat kartuski & miejsko-wiejska & 14611 & 680 \\
\hline 14. & Kępice & powiat słupski & miejsko-wiejska & 3646 & 611 \\
\hline 15. & Kościerzyna & $\begin{array}{c}\text { powiat } \\
\text { kościerski }\end{array}$ & miejska & 23809 & 1586 \\
\hline 16. & Krynica Morska & $\begin{array}{c}\text { powiat nowod- } \\
\text { worski }\end{array}$ & miejska & 1302 & 11601 \\
\hline
\end{tabular}

6 W przypadku gmin miejsko-wiejskich dane dla obszaru miasta. 


\begin{tabular}{|c|c|c|c|c|c|}
\hline Lp. & Miasto & Lokalizacja & Typ gminy & $\begin{array}{c}\text { Liczba ludności } \\
\text { (stan na } \\
\text { 31.12.2017) }\end{array}$ & $\begin{array}{c}\text { Powierzchnia } \\
\text { w ha (stan na } \\
31.12 .2017 \text { ) }\end{array}$ \\
\hline 17. & Kwidzyn & $\begin{array}{c}\text { powiat } \\
\text { kwidzyński }\end{array}$ & miejska & 38553 & 2154 \\
\hline 18. & Lębork & powiat lęborski & miejska & 35413 & 1786 \\
\hline 19. & Łeba & powiat lęborski & miejska & 3694 & 1481 \\
\hline 20. & Malbork & $\begin{array}{c}\text { powiat } \\
\text { malborski }\end{array}$ & miejska & 38723 & 1716 \\
\hline 21. & Miastko & powiat bytowski & miejsko-wiejska & 10605 & 568 \\
\hline 22. & $\begin{array}{c}\text { Nowy Dwór } \\
\text { Gdański }\end{array}$ & $\begin{array}{c}\text { powiat } \\
\text { nowodworski }\end{array}$ & miejsko-wiejska & 9964 & 507 \\
\hline 23. & Nowy Staw & $\begin{array}{c}\text { powiat } \\
\text { malborski }\end{array}$ & miejsko-wiejska & 4196 & 467 \\
\hline 24. & Pelplin & powiat tczewski & miejsko-wiejska & 7912 & 442 \\
\hline 25. & Prabuty & $\begin{array}{c}\text { powiat } \\
\text { kwidzyński }\end{array}$ & miejsko-wiejska & 8710 & 729 \\
\hline 26. & Pruszcz Gdański & powiat gdański & miejska & 30468 & 1647 \\
\hline 27. & Puck & powiat pucki & miejska & 11265 & 479 \\
\hline 28. & Reda & $\begin{array}{c}\text { powiat } \\
\text { wejherowski }\end{array}$ & miejska & 25102 & 3346 \\
\hline 29. & Rumia & $\begin{array}{c}\text { powiat } \\
\text { wejherowski }\end{array}$ & miejska & 48632 & 3010 \\
\hline 30. & Skarszewy & $\begin{array}{c}\text { powiat } \\
\text { starogardzki }\end{array}$ & miejsko-wiejska & 7103 & 1079 \\
\hline 31. & Skórcz & $\begin{array}{c}\text { powiat } \\
\text { starogardzki } \\
\end{array}$ & miejska & 3609 & 363 \\
\hline 32. & Słupsk & $\begin{array}{c}\text { miasto na } \\
\text { prawach powiatu }\end{array}$ & $\begin{array}{c}\text { miasto na } \\
\text { prawach powiatu }\end{array}$ & 91465 & 4315 \\
\hline 33. & Sopot & $\begin{array}{c}\text { miasto na } \\
\text { prawach powiatu }\end{array}$ & $\begin{array}{c}\text { miasto na } \\
\text { prawach powiatu }\end{array}$ & 36533 & 1728 \\
\hline 34. & $\begin{array}{c}\text { Starogard } \\
\text { Gdański }\end{array}$ & $\begin{array}{c}\text { powiat } \\
\text { starogardzki }\end{array}$ & miejska & 48060 & 2528 \\
\hline 35. & Sztum & powiat sztumski & miejsko-wiejska & 10127 & 459 \\
\hline 36. & Tczew & powiat tczewski & miejska & 60257 & 2238 \\
\hline 37. & Ustka & powiat słupski & miejska & 15709 & 1019 \\
\hline 38. & Wejherowo & $\begin{array}{c}\text { powiat } \\
\text { wejherowski }\end{array}$ & miejska & 49927 & 2699 \\
\hline 39. & Władysławowo & powiat pucki & miejska & 10009 & 1259 \\
\hline 40. & Żukowo & powiat kartuski & miejska & 6677 & 473 \\
\hline
\end{tabular}

Źródło: Bank Danych Lokalnych. 
Pod względem aktywności wyborczej mieszkańcy małych i średnich miast województwa pomorskiego nie odbiegają od średniej dla Polski i województwa. Zdecydowanie wyższą frekwencją wyróżniają się Sopot, Jastarnia i Krynica Morska. Niższa frekwencja notowana jest w miastach powiatów człuchowskiego, malborskiego, sztumskiego.

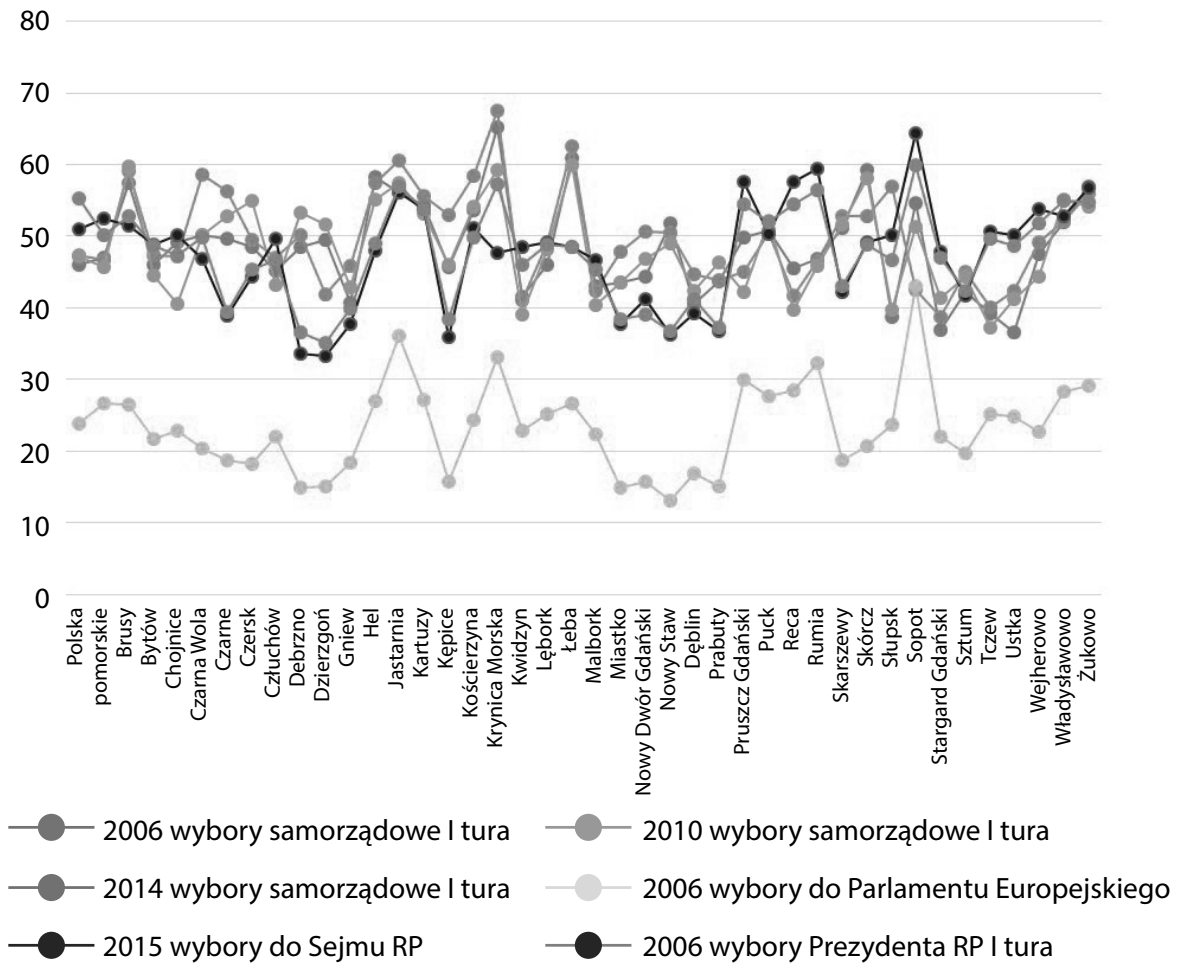

Ryc. 3. Frekwencja wyborcza w małych i średnich miastach województwa pomorskiego w \% Źródło: Państwowa Komisja Wyborcza..., 2015. 


\section{Partycypacja publiczna w małych i średnich miastach województwa pomorskiego ${ }^{7}$}

Analizę możliwości partycypacji publicznej w małych i średnich miastach województwa pomorskiego rozpoczęto od analizy możliwości dostępu do informacji. W tym celu sprawdzono funkcjonalność stron internetowych urzędów miast.

W większości przypadków dostęp do informacji o konsultacjach społecznych na stronach internetowych miast był utrudniony. Jedynie w jednej czwartej przypadków (26\%) zakładka dedykowana konsultacjom społecznym dostępna była bezpośrednio ze strony głównej. W jednej trzeciej miast (39\%) zakładka poświęcona konsultacjom społecznym dostępna była na stronie głównej Biuletynu Informacji Publicznej (dalej: BIP). W prawie połowie przypadków (45\%) informacji o konsultacjach nie można było odnaleźć ani na stronie internetowej miasta, ani w BIP.

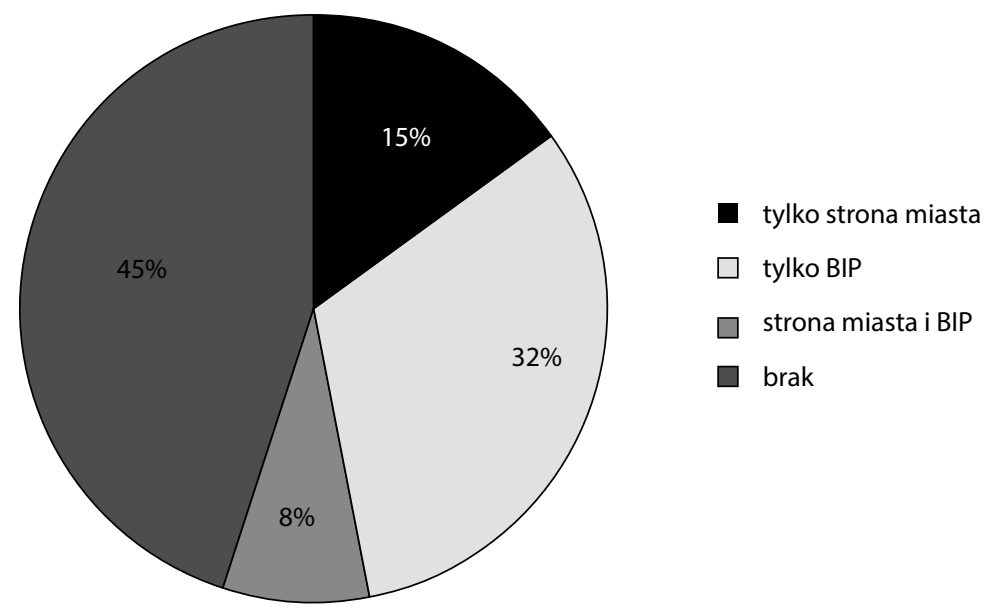

Ryc. 4. Dostępność informacji o partycypacji publicznej (konsultacjach społecznych)

Źródło: opracowanie własne na podstawie danych rozproszonych ${ }^{8}$.

Kolejnym etapem badania było sprawdzenie stopnia wykorzystania form partycypacji publicznej wskazanych w ustawie z dnia 8 marca 1990 r. o samorządzie

7 Ze względu na ograniczenia objętości artykułu przedstawiono wyniki analiz stron internetowych oraz realizacji zapisów ustawy z dnia 8 marca 1990 r. o samorządzie gminnym.

8 Wykres opracowany został na podstawie analizy treści i funkcjonalności oficjalnych stron głównych i biuletynów informacji publicznej małych i średnich miast województwa pomorskiego. Adresy stron znaleźć można w bibliografii. W trakcie analizy uwzględniono: zakres informacji o konsultacjach społecznych, dostępność informacji (czy ww. informacje są umieszczane na stronie lub w BIP, lokalizacja ww. informacji w strukturze stron, czas udostępniania takich informacji), funkcjonalność (ile tzw. kliknięć należy wykonać, aby dotrzeć do informacji o konsultacjach, wersje strony dla osób słabowidzących i niedowidzących). 
gminnym. Połowa miast (50\%) dysponowała regulaminem konsultacji społecznych. 70\% regulaminów uchwalonych zostało w trakcie kadencji 2014-2018. Zasadniczo prawo inicjowania konsultacji przysługuje burmistrzowi, prezydentowi lub radnym miejskim. W 70\% regulaminów z wnioskiem o przeprowadzenie konsultacji mogą wystąpić także mieszkańcy, w trzech miastach - organizacje pozarządowe, $\mathrm{w}$ dwóch rada osiedla, a w jednej młodzieżowa rada miasta. O przeprowadzeniu konsultacji ostatecznie decyduje jednak burmistrz lub prezydent.

W zdecydowanej większości regulaminów (90\%) wskazany jest obowiązek przygotowania raportu, zazwyczaj jest to zdawkowe sformułowanie zobowiązujące do prezentacji wyników konsultacji na tablicy ogłoszeń lub w BIP. Jedynie w przypadku trzech miast pojawił się szczegółowy opis przygotowania, zawartości i sposobu udostępniania takiego raportu.

Wśród wskazywanych technik konsultacyjnych brakuje rozwiązań innowacyjnych. Dominują spotkania otwarte, badania społeczne i konsultacje w formie pisemnej. W ponad jednej trzeciej miast (35\%) katalog technik pozostaje otwarty, można zastosować nowe czy elastyczne techniki, jeżeli będzie wymagał tego temat lub uczestnicy konsultacji.

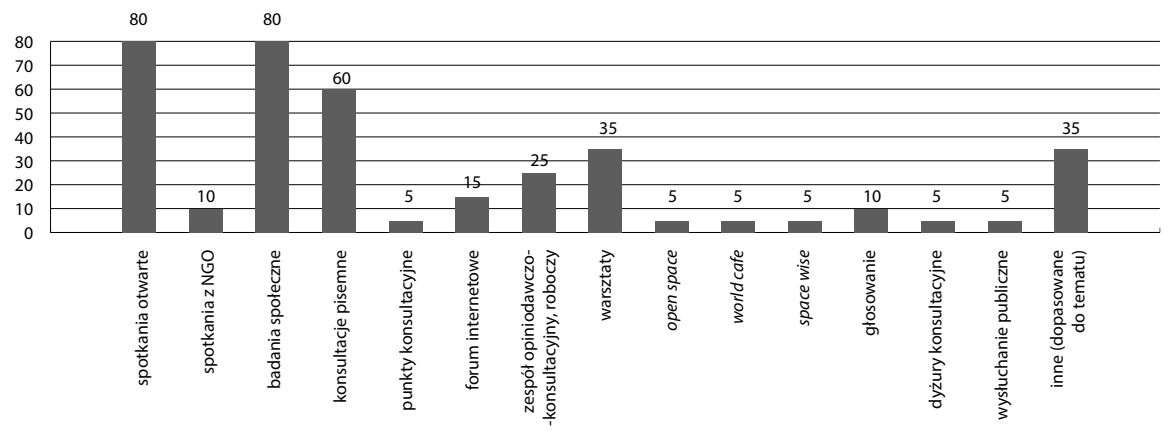

Ryc. 5. Formy konsultacji społecznych w miejskich regulaminach konsultacji w procentach

Źródło: opracowanie własne na podstawie danych rozproszonych ${ }^{9}$.

Wśród nietypowych rozwiązań w analizowanych regulaminach wskazać można miasto Czarne, w którym z inicjatywą przeprowadzenia konsultacji wystąpić może Młodzieżowa Rada Miasta w Czarnem. Inne rozwiązanie stanowi regulamin konsultacji w Słupsku, który wprowadza między innymi publikację planu konsultacji na dany rok, obowiązek prowadzenia konsultacji w co najmniej trzech formach, szczegółowo wskazuje zakres kampanii informacyjnej i treść raportu.

9 Wykres opracowany został na podstawie analizy uchwał rad gminy małych i średnich miast województwa pomorskiego dotyczących przyjęcia regulaminów konsultacji społecznych. Pełen wykaz uchwał odnaleźć można w bibliografii. W trakcie analizy uwzględniono: istnienie lub brak ww. uchwały, a także wskazane w uchwale techniki i metody konsultacji, sposoby informowania, terminy, obowiązek przygotowania i zakres raportu z konsultacji. 
Zobowiązuje również do prowadzenia ewaluacji procesów konsultacyjnych. Pozwala to na wzmacnianie mechanizmów przewidywalności i transparentności partycypacji publicznej.

Błędami pojawiającymi się w regulaminach konsultacji było na przykład niewskazanie żadnej formy konsultacji, łączenie regulaminu konsultacji dla mieszkańców z tym dla organizacji pozarządowych, mylenie poszczególnych technik badań społecznych. Najczęściej pojawiającym się błędem było jednak ograniczenie możliwości udziału ze względu na wiek czy posiadanie czynnego prawa wyborczego - w przypadku konsultacji miejskich na podstawie ustawy z dnia 8 marca 1990 r. o samorządzie gminnym jedynym kryterium dostępu może być miejsce zamieszkania (nawet nie zameldowania).

Najpopularniejszą formą fakultatywnych działań partycypacyjnych jest budżet obywatelski (lub partycypacyjny). Stosowany był w $90 \%$ badanych miast (wyniki przed wprowadzeniem nowelizacji z dnia 11 stycznia 2018 r. ustawy z dnia 8 marca 1990 r. o samorządzie gminnym). Popularność tego mechanizmu wynikać może z realizacji projektów będących odpowiedzią na realne potrzeby mieszkańców, a dzięki temu dających obywatelom poczucie sprawczości. Podkreślić warto, że znaczna część tych projektów powinna być zrealizowana z bieżącego budżetu miast.

W niespełna połowie miast (43\%) funkcjonowały rady seniorów, a w około trzech czwartych (73\%) młodzieżowe rady miasta o charakterze doradczym.

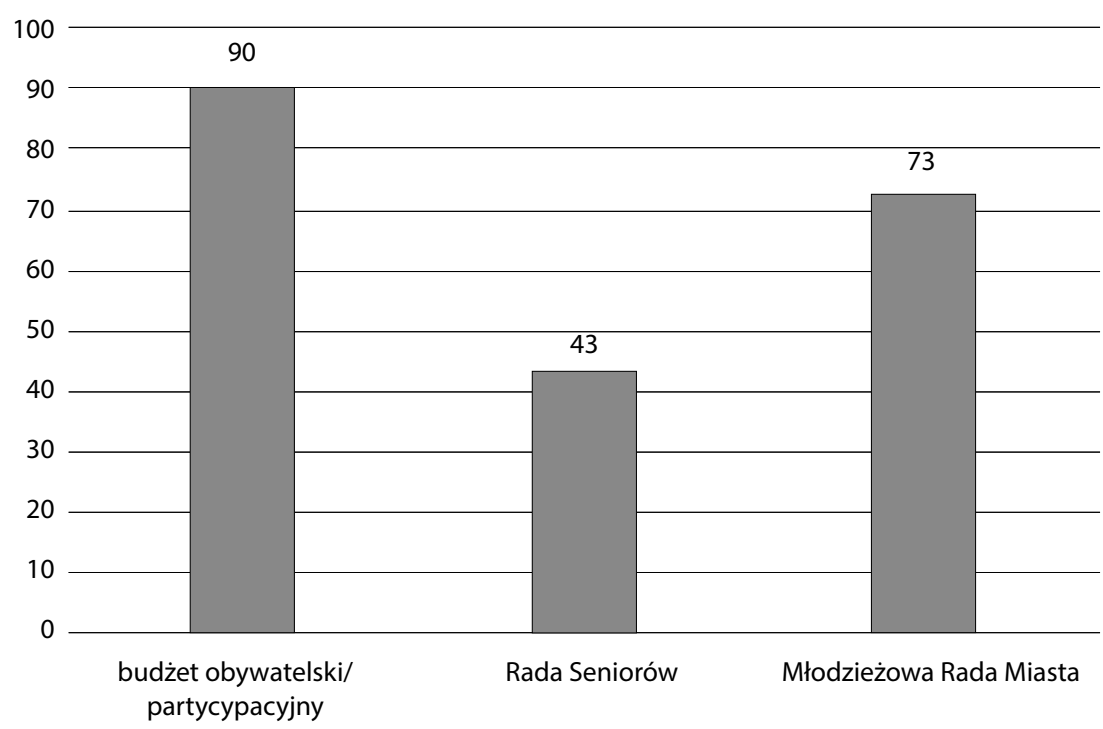

Ryc. 6. Formy partycypacji publicznej wskazane w ustawie o samorządzie gminnym w procentach

Źródło: opracowanie własne na podstawie danych rozproszonych ${ }^{10}$.

10 Wykres opracowany został na podstawie analizy uchwał rad gminy małych i średnich miast województwa pomorskiego dotyczących przyjęcia regulaminów konsultacji społecznych. Uzupeł- 
Przeprowadzone analizy wskazują na sposób organizowania partycypacji przez władze samorządowe. Stronę społeczną prezentują fragmenty wypowiedzi z badań jakościowych przeprowadzonych przez autorkę w 2017 roku z przedstawicielami organizacji pozarządowych ${ }^{11}$. Charakterystyczne, powtarzające się wątki widoczne są w przedstawionych cytatach:

1. „Urzędy nie są zainteresowane żadnym głosem mieszkańców, chyba że potrzebują podkładki do finansowania".

2. „Mieszkańcy są traktowani instrumentalnie, są zapraszani do udziału w konsultacjach tylko dlatego, że taki jest wymóg formalny, nikt się nie liczy z głosem i potrzebami mieszkańców".

3. „Konsultacje często mają formę jedynie informacyjną. Władze i tak zrobią po swojemu".

4. „Władza nie działa jawnie i w imieniu wszystkich mieszkańców”.

5. ,Jednostki pomocnicze traktowane są jako zawory bezpieczeństwa, a nie narzędzie partycypacji”.

6. „Zarozumiałość, rutyna, myślenie kadencyjne, lokalne uwikłania biznesowo-samorządowe".

7. „Próby sterowania organizacjami pozarządowymi poprzez zinstytucjonalizowanie. Wyznaczenie pełnomocnika centrum organizacji pozarządowych”.

\section{Próba podsumowania}

Podsumowując wyniki przeprowadzonych badań, wskazać należy przede wszystkim na:

1) utrudniony dostęp mieszkańców do informacji o realizowanych projektach, przygotowywanych politykach publicznych, dokumentacji procesów partycypacyjnych,

2) brak informacji zwrotnej ze strony władz (np. raporty z konsultacji),

3) brak platformy dialogu i współpracy władz miejskich z mieszkańcami,

4) ilościowe podejście do procesów partycypacyjnych - o sukcesie w opinii władz decyduje liczba spotkań i uczestników konsultacji, a nie liczba uwzględnionych wniosków i uwag czy jakość przygotowanego projektu.

Tak więc wstępnie potwierdza się hipoteza o ograniczonym dostępie obywateli do procesów partycypacji publicznej w małych i średnich miastach. Analizowane przypadki wskazują na umożliwianie mieszkańcom udziału w konsultacjach,

nieniem jest analiza informacji i raportów z prowadzonych konsultacji udostępnionych na stronach małych i średnich miast województwa pomorskiego wskazanych w bibliografii.

11 Badanie realizowane w 2017 roku, w dwóch turach, przy udziale 32 i 16 respondentów i respondentek z polskich miast - przedstawicieli samorządów miejskich i organizacji pozarządowych związanych z Kongresem Ruchów Miejskich. Pytania dotyczyły między innymi zasad i zakresu konsultacji i partycypacji stosowanych przez samorządy miejskie, sposobu i zakresu komunikacji, oceny respondentów ww. działań, sposobu angażowania się respondentów w konsultacje oraz preferowanych i pożądanych przez respondentów sposobów współpracy samorządu z mieszkańcami. 
partycypacji jedynie w zakresie wskazywanym przez ustawy. Dominuje sztywny katalog metod i technik konsultacji, dominują konsultacje pisemne, komunikacja jednostronna. Porównanie siedmiu zasad konsultacji i sposobu prowadzenia konsultacji w badanych miastach wskazuje przede wszystkim na brak dostępu do informacji, co zasadniczo uniemożliwia realizację mechanizmów postulowanych w Kanonie lokalnych konsultacji spotecznych. Sytuację w badanych miastach można odnieść do klasycznej drabiny partycypacji autorstwa Sherry R. Arnstein [1969]. Stopnie drabiny partycypacji wskazują drogę od braku do pełnej partycypacji publicznej. Badane miasta lokują się na dolnych szczeblach, między manipulacją a informowaniem. Sytuację $w$ badanych miastach obrazuje także opis działań partycypacyjnych jako koszmaru. Marcus Miessen [2013] opisuje partycypację jako szereg działań pozorowanych, angażujących czas i energię mieszkańców. Działania te nie mają przełożenia na realne decyzje polityczne, oderwane są od sprawczości mieszkańców. To rodzaj zasłony dymnej dla kryzysu ekonomicznego i skupianie uwagi na małych inwestycjach (np. urządzanie przestrzeni publicznych), a nie na decyzjach strategicznych.

Jakie konsekwencje może przynieść traktowanie partycypacji i konsultacji jako procesu pozornego, bez realnego wpływu mieszkańców na swoje miasta? Przede wszystkim utrudnia to budowanie kapitału społecznego (niższe: aktywność społeczna, frekwencja wyborcza, poczucie sprawczości) oraz realizację celów strategicznych zapisanych w SOR. Może negatywnie wpływać na jakość stanowionego prawa lokalnego i polityk publicznych. Może prowadzić do realizacji projektów niezgodnych z potrzebami mieszkańców, odbiegających od lokalnych uwarunkowań.

W dłuższej perspektywie ograniczenie udziału mieszkańców w partycypacji publicznej wpływać może na obniżenie jakości życia w miastach. Coraz częściej wskaźniki związane z aktywnością obywatelską włączane są do oceny jakości życia ${ }^{12}$.

Czy można przeciwdziałać tym negatywnym zjawiskom? Jedną z możliwych ścieżek jest promocja i popularyzacja dobrych praktyk. Przeprowadzone badania wskazują, że to działania niewystarczające - JST realizują działania partycypacyjne jedynie w minimalnym zakresie wymaganym przez prawo. Konieczne są zmiany systemowe, przede wszystkim w zakresie prawa, które mobilizować będzie władze lokalne do współpracy z mieszkańcami. Przykładem może być opisana powyżej ustawa z dnia 9 października 2015 r. o rewitalizacji, która pokazała, że konsultacje mogą być prowadzone z mieszkańcami, blisko ich domów, $\mathrm{w}$ odpowiedzi na lokalne potrzeby i problemy. Podobny efekt mogłoby przynieść wprowadzenie Kodeksu urbanistyczno-budowlanego (dalej: KUB), który szeroko reguluje proces partycypacyjny w planowaniu przestrzennym. Projekt KUB wprowadza między innymi obowiązek realizacji dyskusji publicznych na projektowanym terenie, w godzinach dogodnych dla mieszkańców. Wprowadza także obowiązek jawnego dokumentowania całego procesu projektowego i partycypacyjnego. Rozwiązania

12 Por. Międzynarodowy statut..., 2014; Diagnoza społeczna..., 2015; Regional Well-Being..., 2016; Jakość życia ..., 2017, Jakość życia ..., 2018. 
KUB pozwalają na urzeczywistnienie zasad Kanonu lokalnych konsultacji społecznych. Taki jest rekomendowany przez autorkę kierunek zmian.

\section{Bibliografia}

\section{Akty prawne}

Konstytucja Rzeczypospolitej Polskiej z dnia 2 kwietnia 1997 r., Dz.U. 1997, nr 78, poz. 483 ze zm.

Krajowa Polityka Miejska 2023. Dokument przyjęty uchwałą nr 198 Rady Ministrów z dnia 20 października 2015 r., M.P. 2015, poz. 1235.

Projekt ustawy Kodeks urbanistyczno-budowlany, Rządowe Centrum Legislacji, https://legislacja.rcl.gov.pl/projekt/12290463/katalog/12382112\#12382112 [dostęp: 3.12. 2018].

Uchwała nr LIV/574/2006 Rady Miejskiej Rumi z dnia 28 września 2006 r. Zasady i tryb przeprowadzania konsultacji społecznych z mieszkańcami miasta Rumi.

Uchwała nr XI/143/2007 Rady Miasta Sopotu z dnia 30 listopada 2007 r. w sprawie: zasad i trybu przeprowadzenia konsultacji z mieszkańcami Sopotu.

Uchwała nr IV/25/2011 Rady Miejskiej w Kępicach z dnia 27 stycznia 2011 r. w sprawie określenia zasad i trybu przeprowadzenia konsultacji społecznych, Dz.Urz. Woj. Pomorskiego 2011, poz. 34.

Uchwała nr XX/148/11 Rady Miasta Kościerzyna z dnia 1 grudnia 2011 r. w sprawie zasad i trybu przeprowadzania konsultacji z mieszkańcami Gminy Miejskiej Kościerzyna.

Uchwała nr 239 Rady Ministrów z dnia 13 grudnia 2011 r. w sprawie przyjęcia Koncepcji Przestrzennego Zagospodarowania Kraju 2030, M.P. 2012, poz. 252.

Uchwała nr XXIX/249/2013 Rady Miejskiej w Bytowie z dnia 27 marca 2013 r. w sprawie zasad i trybu przeprowadzania konsultacji społecznych z mieszkańcami gminy Bytów, Dz.Urz. Woj. Pomorskiego 2013, poz. 2050.

Uchwała nr XXXVIII/390/2013 Rady Miejskiej w Żukowie z dnia 19 września 2013 r. w sprawie zasad i trybu przeprowadzenia konsultacji z mieszkańcami Gminy Żukowo, Dz.Urz. Woj. Pomorskiego 2013, poz. 3403.

Uchwała nr VII/31/2015 Rady Miejskiej w Prabutach z dnia 29 kwietnia 2015 r. w sprawie określenia zasad i trybu przeprowadzania konsultacji społecznych z mieszkańcami Miasta i Gminy Prabuty.

Uchwała nr X/81/2015 Rady Miejskiej Rumi z dnia 28 maja 2015 r. zmieniająca uchwałę nr LIV/574/2006 Rady Miejskiej Rumi z dnia 28 września 2006 r. w sprawie zasad i trybu przeprowadzania konsultacji społecznych z mieszkańcami miasta Rumia, Dz.Urz. Woj. Pomorskiego 2015, poz. 2564.

Uchwała nr 0007.30.2015 Rady Miejskiej w Czarnem z dnia 1 czerwca 2015 r. w sprawie wprowadzenia Regulaminu Konsultacji Społecznych Miasta i Gminy Czarne, Dz.Urz. Woj. Pomorskiego 2015, poz. 2001. 
Uchwała nr 67.XVII.2015 Rady Miejskiej w Debrznie z dnia 24 lipca 2015 r. w sprawie wprowadzenia Regulaminu Konsultacji Społecznych Miasta i Gminy Debrzno, Dz.Urz. Woj. Pomorskiego 2015, poz. 2564.

Uchwała nr 100/X/2015 Rady Miejskiej w Nowym Dworze Gdańskim z dnia 22 października 2015 r. w sprawie wprowadzenia Regulaminu Konsultacji Społecznych Gminy Nowy Dwór Gdański, Dz.Urz. Woj. Pomorskiego 2015, poz. 3488.

Uchwała nr XVI/123/2015 Rady Miejskiej w Miastku z dnia 23 października 2015 r. w sprawie zasad i trybu przeprowadzania konsultacji społecznych z mieszkańcami Gminy Miastko, Dz.Urz. Woj. Pomorskiego 2015, poz. 3383.

Uchwała nr XVI/173/2015 Rady Miejskiej Władysławowa z dnia 25 listopada 2015 r. w sprawie: określenia zasad i trybu przeprowadzania konsultacji społecznych z mieszkańcami Gminy Władysławowo, Dz.Urz. Woj. Pomorskiego 2015, poz. 4390.

Uchwała nr XXI/238/16 Rady Miejskiej w Słupsku z dnia 27 stycznia 2016 r. Słupski Regulamin Konsultacji Społecznych.

Uchwała nr XV/188/2016 Rady Miejskiej w Łebie z dnia 8 lutego 2016 r. w sprawie wprowadzenia Regulaminu Konsultacji Społecznych, Dz.Urz. Woj. Pomorskiego 2016, poz. 774.

Uchwała nr XVII/137/2016 Rady Miejskiej w Tczewie z dnia 31 marca 2016 r. w sprawie określenia zasad przeprowadzenia konsultacji społecznych wśród mieszkańców miasta Tczewa oraz konsultacji projektów aktów prawa miejscowego z radami działalności pożytku publicznego, organizacjami pozarządowymi z innymi uprawnionymi podmiotami.

Uchwała nr XXI/197/2016 Rady Miejskiej w Redzie z dnia 29 czerwca 2016 r. w sprawie zasad i trybu przeprowadzania konsultacji społecznych z mieszkańcami Gminy Miasto Reda.

Uchwała nr XXIV/237/2016 Rady Miasta Ustka z dnia 29 września 2016 r. w sprawie w sprawie zasad i trybu przeprowadzania konsultacji z mieszkańcami Gminy Miasto Ustka, Dz.Urz. Woj. Pomorskiego 2016, poz. 3856.

Uchwała nr 8 Rady Ministrów z dnia 14 lutego 2017 r. w sprawie przyjęcia Strategii na rzecz odpowiedzialnego rozwoju do roku 2020 (z perspektywą do 2030 r.), M.P. 2017, poz. 260.

Uchwała nr XXVII/139/2017 Rady Miejskiej w Skórczu z dnia 27 kwietnia 2017 r. w sprawie zasad i trybu przeprowadzania konsultacji społecznych, Dz.Urz. Woj. Pomorskiego 2017, poz. 2066.

Uchwała nr 285/XXXIX/2017 Rady Miejskiej w Nowym Stawie z dnia 29 czerwca 2017 r. w sprawie określenia zasad i trybu przeprowadzania konsultacji społecznych z mieszkańcami Gminy Nowy Staw.

Uchwała nr XXI/205/17 Rady Miejskiej w Brusach z dnia 4 sierpnia 2017 r. w sprawie przyjęcia zasad i trybu przeprowadzania konsultacji społecznych z mieszkańcami gminy Brusy, Dz.Urz. Woj. Pomorskiego 2017, poz. 3133.

Ustawa z dnia 8 marca 1990 r. o samorządzie gminnym, Dz.U. 2019, poz. 506 tekst jedn.

Ustawa z dnia 7 września 1991 r. o systemie oświaty, Dz.U. 2018, poz. 1457 tekst jedn. ze zm. Ustawa z dnia 15 września 2000 r. o referendum lokalnym, Dz.U. 2019, poz. 741 tekst jedn.

Ustawa z dnia 27 kwietnia 2001 r. Prawo ochrony środowiska, Dz.U. 2018, poz. 799 tekst jedn. ze zm.

Ustawa z dnia 27 marca 2003 r. o planowaniu i zagospodarowaniu przestrzennym, Dz.U. 2018, poz. 1945 tekst jedn. ze zm. 
Ustawa z dnia 24 kwietnia 2003 r. o działalności pożytku publicznego i o wolontariacie, Dz.U. 2019, poz. 688 tekst jedn.

Ustawa z dnia 3 października 2008 r. o udostępnianiu informacji o środowisku i jego ochronie, udziale społeczeństwa w ochronie środowiska oraz o ocenach oddziaływania na środowisko, Dz.U. 2018, poz. 2081 tekst jedn. ze zm.

Ustawa z dnia 25 czerwca 2010 r. o sporcie, Dz.U. 2018, poz. 1263 tekst jedn. ze zm.

Ustawa z dnia 9 października 2015 r. o rewitalizacji, Dz.U. 2018, poz. 1398 tekst jedn. ze zm.

Ustawa z dnia 11 stycznia 2018 r. o zmianie niektórych ustaw w celu zwiększenia udziału obywateli w procesie wybierania, funkcjonowania i kontrolowania niektórych organów publicznych, Dz.U. 2018, poz. 130.

\section{Literatura}

Arnstein S.R. (1969), A Ladder Of Citizen Participation, „Journal of the American Planning Association", 4 (35).

Barber B. (2014), Gdyby burmistrzowie rządzili światem: dysfunkcyjne kraje, rozkwitające miasta, tłum. H. Jankowska, K. Makaruk, Muza, Warszawa.

Miessen M. (2013), Koszmar partycypacji, tłum. M. Choptiany, Bęc Zmiana, Warszawa.

Misztal W. (2008), Lokalny dialog obywatelski, Centrum Partnerstwa Społecznego „Dialog”, Warszawa.

Rybicki P. (1972), Społeczeństwo miejskie, PWN, Warszawa.

Schimanek T. (2015), Partycypacja obywatelska w społeczności lokalnej, Fundacja Inicjatyw Społeczno-Ekonomicznych, Warszawa.

Śleszyński P. (2016), Delimitacja miast średnich tracacych funkcje społeczno-gospodarcze, Instytut Geografii i Przestrzennego Zagospodarowania PAN, Warszawa.

Śleszyński P., Bański J., Degórski M., Komornicki T. (2017), Delimitacja obszarów strategicznej interwencji państwa: obszarów wzrostu i obszarów problemowych, Instytut Geografii i Przestrzennego Zagospodarowania PAN, Warszawa.

\section{Raporty i opracowania statystyczne}

Bank danych lokalnych, Główny Urząd Statystyczny, www.stat.gov.pl [dostęp: 3.12.2018].

Jakość życia w Polsce. Edycja 2017 (2017), Główny Urząd Statystyczny, Warszawa.

Poczucie wpływu na sprawy publiczne (2018), CBOS, Warszawa.

Światta małego miasta. Jak się żyje w najmniejszych polskich miastach (2017), Narodowe Centrum Kultury, www.nck.pl [dostęp: 30 kwietnia 2018 roku].

\section{Źródła internetowe}

Brusy Miasto i Gmina, www.brusy.pl [dostęp: 3.12.2018].

Czarna Woda - Urząd Miejski - Oficjalny [s]erwis Urzędu Miejskiego, www.czarna-woda.pl [dostęp: 3.12.2018]. 
Człuchów, www.czluchow.eu [dostęp: 3.12.2018].

Debrzno: Urząd Miejski w Debrznie, www.debrzno.pl [dostęp: 3.12.2018].

Diagnoza społeczna - warunki i jakość życia Polaków (2015), www.diagnoza.com [dostęp: 3.12.2018].

Gdańsk - oficjalny portal miasta, www.gdansk.pl [dostęp: 3.12.2018].

Gdańsk - oficjalny portal miasta. [Panel obywatelski], www.gdansk.pl/panel-obywatelski [dostęp: 3.12.2018].

Gmina Kępice, www.kepice.pl [dostęp: 3.12.2018].

Gmina Miastko, www.miastko.pl [dostęp: 3.12.2018].

Gmina Pelplin, www.pelplin.pl [dostęp: 3.12.2018].

Gmina Żukowo, www.zukowo.pl [dostęp: 3.12.2018].

Hel - Początek Polski, www.gohel.pl [dostęp: 3.12.2018].

Jastarnia, www.jastarnia.pl [dostęp: 3.12.2018].

Kartuzy.pl, www.kartuzy.pl [dostęp: 3.12.2018].

Konsultacje spoteczne. Miasto Stołeczne Warszawa, www.konsultacje.um.warszwa.pl [dostęp: 3.12.2018].

Kościerzyna, www.koscierzyna.gda.pl [dostęp: 3.12.2018].

Krynica Morska: noclegi, wczasy, urlop, wakacje, atrakcje, www.krynicamorska.pl [dostęp: 3.12.2018].

Kwidzyn: Miejski [s]erwis [i]nternetowy, www.kwidzyn.pl [dostęp: 3.12.2018].

Laboratorium Innowacji Społecznych, www.lis.gdynia.pl [dostęp: 3.12.2018].

Lębork - miasto z europejska klasq, www.lebork.pl [dostęp: 3.12.2018].

Łeba Miasto Żywiołów - strona miejska Łeby, www.leba.eu [dostęp: 3.12.2018].

Malbork, www.malbork.pl [dostęp: 3.12.2018].

Miasto i Gmina Gniew: Strona główna, www.gniew.pl [dostęp: 3.12.2018].

Miasto i Gmina Prabuty - serwis informacyjny Prabut, www.prabuty.pl [dostęp: 3.12.2018].

Miasto Puck, www.miastopuck.pl [dostęp: 3.12.2018].

Międzynarodowy statut miast „Cittaslow” (2014), Cittaslow Polska, www.cittaslow.pl [dostęp: 3.12.2018].

Nowy Dwór Gdański | Miasto i Gmina, www.miastonowydwor.pl [dostęp: 3.12.2018].

Nowy Staw, www.nowystaw.pl [dostęp: 3.12.2018].

Obszar Metropolitalny Gdańsk Gdynia Sopot, www.metropoliagdansk.pl [dostęp: 3.12.2018].

Państwowa Komisja Wyborcza - Strona główna (2015), www.pkw.gov.pl [dostęp: 3.12.2018].

Poznan.pl: Strona główna, www.poznan.pl [dostęp: 3.12.2018].

Reda - Urzad Miasta Redy - Serwis informacyjny miasta Redy, www.reda.pl [dostęp: 3.12.2018].

Regional Well-Being OECD (2016), https://www.oecdregionalwellbeing.org [dostęp: 3.12.2018].

Rozwój Lokalny Kierowany przez Społeczność (RLKS), https://www.gov.pl/web/rolnictwo/ rozwoj-lokalny-kierowany-przez-spolecznosc-rlks [dostęp: 27.05.2019].

Rumia - naturalnie pomystowa, www.rumia.eu [dostęp: 3.12.2018].

„, Sąd obywatelski” w sprawie ul. Umultowskiej, www.poznan.pl/mim/main/sad-obywatelski-w-sprawie-ul-umultowskiej,p,15574,21903.html [dostęp: 3.12.2018].

Skórcz, www.skorcz.pl [dostęp: 3.12.2018].

Stupsk, www.slupsk.pl [dostęp: 3.12.2018]. 
Sopocka Inicjatywa Rozwojowa, http://www.sopockainicjatywa.org [dostęp: 3.12.2018].

Sopot.pl - Witamy na stronie miejskiej..., www.sopot.pl [dostęp: 3.12.2018].

Starogard Gdański - Tu rodza się gwiazdy - Informacje o Starogardzie Gdańskim, www.starogard.pl [dostęp: 3.12.2018].

Strona główna - Skarszewy - oficjalna strona miasta i gminy, www.skarszewy.pl [dostęp: 3.12.2018].

Sztum - oficjalny portal internetowy Miasta i Gminy Sztum, www.sztum.pl [dostęp: 3.12.2018].

Twoja Dąbrowa! - Dąbrowski Budzet Partycypacyjny 2020, https://www.twojadabrowa.pl [dostęp: 3.12.2018].

Urząd Miasta i Gminy Czarne - województwo pomorskie, www.czarne.pl [dostęp: 3.12.2018].

Urząd Miasta w Pruszczu Gdańskim, www.pruszcz-gdanski.pl [dostęp: 3.12.2018].

Urzą Miejski w Bytowie, www.bytow.com.pl [dostęp: 3.12.2018].

Urząd Miejski w Chojnicach - Oficjalny serwis Urzędu Miejskiego, www.miastochojnice.pl [dostęp: 3.12.2018].

Urząd Miejski w Czersku, www.czersk.pl [dostęp: 3.12.2018].

Urząd Miejski w Dzierzgoniu, www.dzierzgon.pl [dostęp: 3.12.2018].

Ustka - Oficjalna strona miasta, www.ustka.pl [dostęp: 3.12.2018].

Wejherowo.pl, www.wejherowo.pl [dostęp: 3.12.2018].

Władysławowo, www.wladyslawowo.pl [dostęp: 3.12.2018].

Wrota Tczewa - Miejski Serwis Internetowy, www.wrotatczewa.pl [dostęp: 3.12.2018].

\section{Inne dokumenty i opracowania}

Kanon lokalnych konsultacji społecznych (2015), Fundacja Inicjatyw Społeczno-Ekonomicznych, Warszawa.

Nowa Agenda Miejska. Habitat III (2016).

Urban Agenda for the EU. Pact of Amsterdam (2016). 